
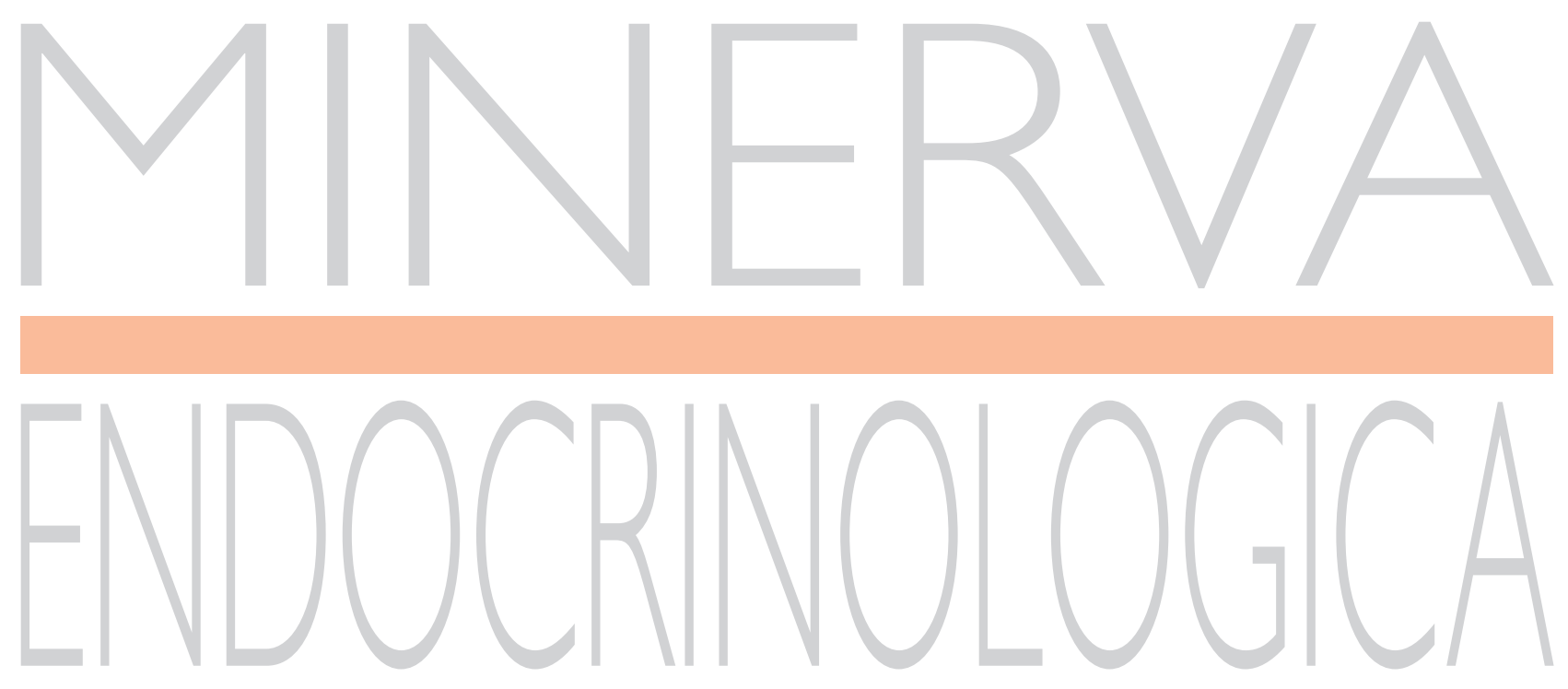

$V O L U M E 44$. No. I. MARCH 20019

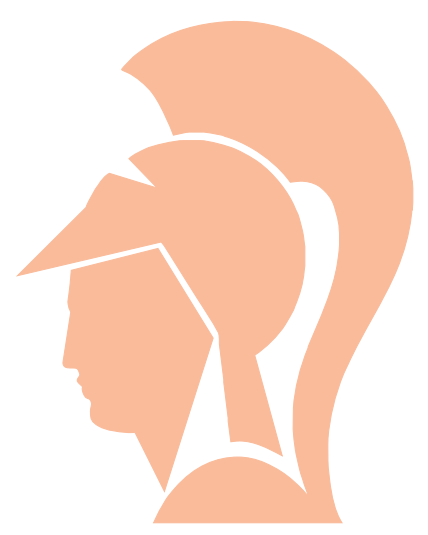

$E D|Z| O N|\cdot M| N E R \vee A$. MED I C A 


\title{
The role of insulin-like growth factor system in the adrenocortical tumors
}

\author{
Barbara ALTIERI 1,2*, Annamaria COLAO 2, Antongiulio FAGGIANO 2
}

1Division of Endocrinology and Diabetes, Department of Internal Medicine I, University Hospital, University of Wuerzburg, Wuerzburg, Germany; '2Department of Clinical Medicine and Surgery, University "Federico II", Naples, Italy

*Corresponding author: Barbara Altieri, Division of Endocrinology and Diabetes, Department of Internal Medicine I, University Hospital of Wuerzburg, Oberduerrbacher-Str 6, 97080 Wuerzburg, Germany. E-mail: altieri.barbara@gmail.com

\section{A B S T R A C T}

INTRODUCTION: The different presentation of adrenocortical tumors in benign adenoma (ACA) or adrenocortical carcinoma (ACC) is related to the variability at the molecular level. The insulin-like growth factor (IGF) system is one of the most frequently altered pathways in ACC. In this review we will critically analyze the evidence regarding the pathogenic role of the IGF system in adrenal tumorigenesis, focusing on ACC. We will also examine the preclinical and clinical studies which investigated the targeting of the IGF system as a therapeutic approach in ACC.

EVIDENCE ACQUISITION: The IGF system plays a crucial role in the embryogenesis of adrenal glands. No significant alterations of the IGF system were observed in ACA. In ACC, the IGF2 overexpression is one of the most frequent molecular change presented in more than $85 \%$ of cases. However, IGF2 seems to be only a tumor progression factor which requires additional hits to trigger adrenal tumorigenesis. Also, the IGF1 receptor (IGF1R) appears to be higher expressed in ACC. Many IGF1R target-drugs have been developed to inhibit the activation of the IGF system.

EVIDENCE SYNTHESIS: Preclinical studies using antibody or tyrosine kinase which target the IGF1R, or the dualtargeting of IGF1R and insulin receptor (IR) reduced ACC cells proliferation both in vitro and in vivo in mouse xenograft model. However, these promising results were not confirmed in clinical trials.

CONCLUSIONS: Nowadays, predictive markers for the response of target-IGF therapy are missing and further studies which investigate new molecular markers and evaluate the entire IGF receptors, including the IR, are urgently needed.

(Cite this article as: Altieri B, Colao A, Faggiano A. The role of insulin-like growth factor system in the adrenocortical tumors. Minerva Endocrinol 2019;44:43-57. DOI: 10.23736/S0391-1977.18.02882-1)

KEY WORDS: Adrenal cortex neoplasms - Insulin-like growth factor - Receptor, IGF type 1 - Receptor, insulin.

\section{Introduction}

A drenocortical tumors (ACT) are frequent in the general population and are mostly incidentally discovered with a prevalence ranges from $1 \%$ to $10 \%$ in the elderly. ${ }^{1}$ Most of them are benign adrenocortical adenomas (ACA) that can be non-functioning in $70-80 \%$ of cases or associated with autonomous cortisol secretion or, more rarely, with aldosterone secretion. ${ }^{1}$ In- stead, adrenocortical carcinomas (ACC) are rare aggressive tumors with an annual incidence of 0.7-2.0 cases per million per year ${ }^{2,3}$ and with an overall survival (OS) rate at five years ranging from $15 \%$ to $80 \%$ according to tumor stage. ${ }^{4}$ The majority of ACC patients present symptoms associated with hormone excess, more frequently with hypercortisolism (Cushing Syndrome) or mixed Cushing's and virilizing syndrome, whereas aldosterone or estrogen excess 
is rare. ${ }^{2,} 5$ About $30-40 \%$ of ACC is associated with non-specific symptoms due to the tumor mass, such as flank or back pain or abdominal discomfort, and the remaining $10 \%$ is discovered as incidentalomas. ${ }^{2,5}$

The different presentation of an ACT in benign or malignant neoplasia is related to the variability at molecular level. ${ }^{6}$ In the last decades, several genomics studies have been tried to better understand the pathophysiology underlying the molecular mechanisms involved in the ACT development.7-11 In comparison to ACA, ACC has thousands of genes deregulated, mostly implicated in the cell-cycle regulation, chromosomal modelling, apoptosis, inflammation and immunity. ${ }^{6}, 12-16$ The insulin-like growth factor (IGF) system is one of the most frequently altered pathways in ACC, even though it also plays a significant role in the regulation of different biological functions in normal adrenal glands. ${ }^{17,} 18$ Notably, the IGF2 overexpression represents a hallmark of ACC and is observed in more than $85 \%$ of cases. $6,8,12,17,18$ This overexpression results in activation of the IGF1 receptor (IGF1R) and, consequently, of the entire IGF signaling pathway. ${ }^{17}$ IGF1R seems to be involved in ACC tumorigenesis ${ }^{19}$ and different preclinical studies, which investigated the targeting of this receptor showed promising results. ${ }^{20-22}$ However, phase I and III trials evaluating two pharmaceutical agents, figitumumab and linsitinib, targeting the IGF1R and both IGF1R - insulin receptor (IR), respectively, failed to demonstrate significant clinical benefit, except in a few patients. ${ }^{23,24}$ One of the lack of these studies was that predictive biomarkers, such as the evaluation of the IGF system members, which were necessary for the identification of the probable responders, were not used. ${ }^{25}$

In this review, we perform a comprehensive evaluation of the physiological role of IGF system in the adrenal gland and its pathogenetic involvement in the development of ACT. Moreover, we focus our attention also in studies and clinical trials investigating different molecules that target the IGF system in preclinical models of ACC and/or ACC patients, critically discussing the weaknesses of these studies and underlying the future prospective of these molecules.

\section{Evidence acquisition}

An overview of the IGF system signaling pathway and its correlation with cancer

The IGF system has a critical role in the growth and metabolism of many tissues, as well as is involved in the progression of several cancer types (Figure 1).17, 19, 22, 25-33 The IGF system is a complex pathway that includes several components: three ligands (IGF1, IGF2, and insulin), three receptors (IGF1R, mannose-6 phosphate IGF2 receptor [M6P/IGF2R], and IR), and six different IGF-binding proteins (IGFBP-1 to 6). ${ }^{31}$

The IGF1 and IGF2 are mostly produced by the liver or secreted locally by different tissues, such as cancer cells, acting via paracrine and autocrine signaling in addition to endocrine mechanisms. ${ }^{34}$ On the contrary, insulin, which is structurally similar to IGF, is produced only by pancreatic beta cells and can act only via endocrine mechanism. IGF peptides circulate bound to IGF-BP, which prevent their interaction with the receptors, whereas insulin circulates mainly in free form. ${ }^{31}$

The IGF1R and the IR are transmembrane tyrosine kinase receptors with a high grade of homology. They are both heterotetramers composed of two extracellular $\alpha$-subunits, which include the ligand-binding domain, and two transmembrane $\beta$-subunits, which possess the tyrosine kinase domain. ${ }^{35}$ IGF1R binds IGF1 and IGF2 with high affinity and insulin with low affinity. ${ }^{17}$ To better understand the complex correlation between IGF system and tumorigenesis, it is important to note that there are two isoforms of IR generated by alternative splicing of the exon 11.17, 36, 37 This region encodes 12 amino acids at the $\mathrm{C}$-terminus of the $\alpha$-subunit which are excluded (IR-A) or included (IR-B) in the two isoforms. ${ }^{37}$ The expression of these isoforms is tissue-specific: IR-B is express in metabolic tissues, such as liver, muscle and adipose tissue and activates the metabolic pathway through the binding of insulin, whereas IR-A is preferentially expressed in fetal tissues and cancer cells, as well as in central nervous system and hematopoietic cells, and binds both insulin and IGF2.36,38-40 Due to the high homology between IGF1R and IR, their monomer $\alpha / \beta$ can mix and create hybrid recep- 


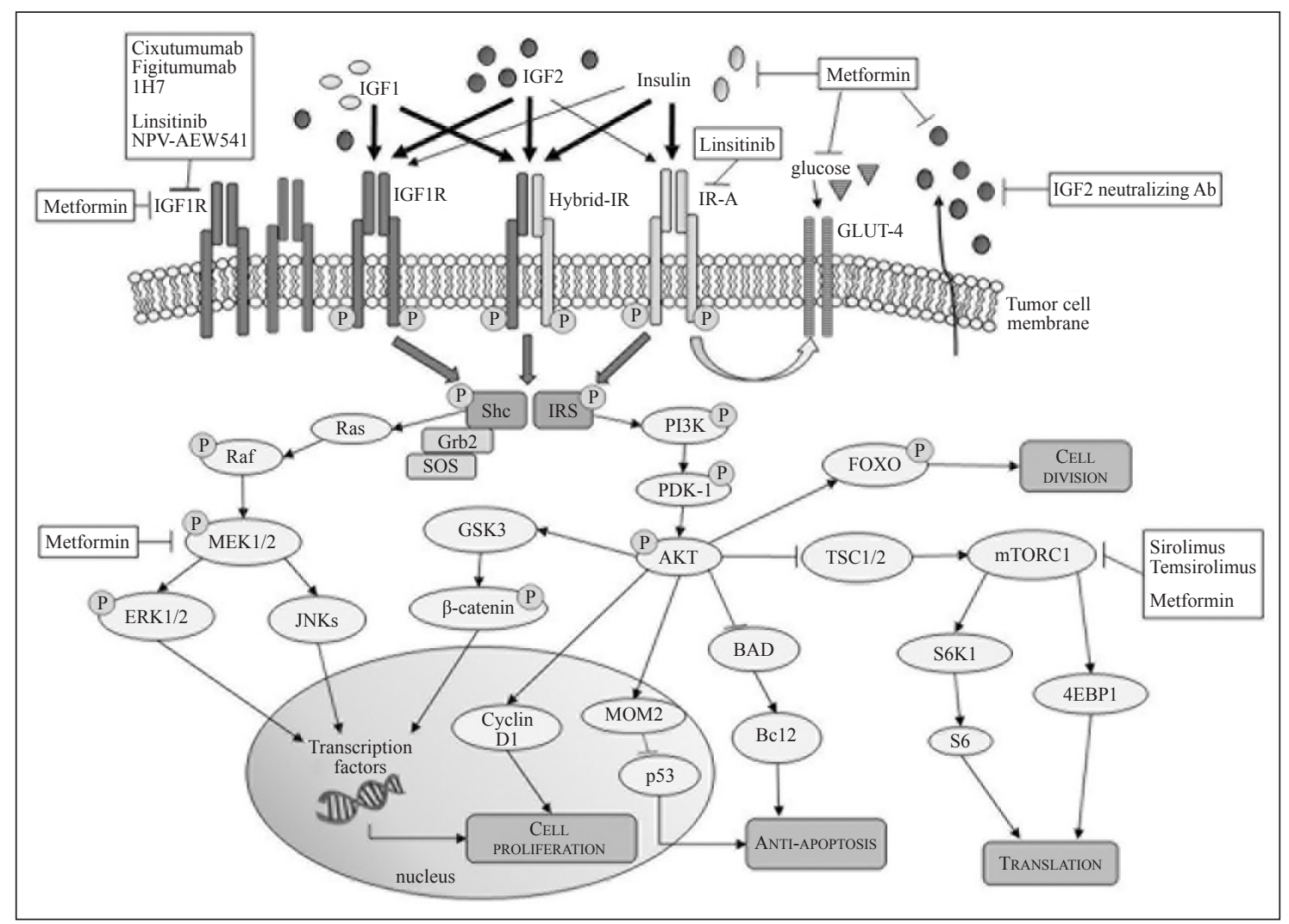

Figure 1.-IGF1R/IR cellular signaling pathway and IGF-target agents in adrenocortical tumor cells.

Schematic diagram of the alterations of the insulin-like growth factor (IGF) pathway involved in adrenocortical tumorigenesis and IGF-target agents in adrenocortical carcinoma (ACC) cells. Ligand binding to IGF1 receptor (IGF1R), insulin receptor-A (IRA) or hybrid-receptor A (Hybrid-RA) leads to the autophosphorylation of the tyrosine kinase subunit and the activation of the insulin receptor substrate (IRS) or the SRC homology and collagen (Shc). Ligands are represented by IGF1, IGF2 and insulin and thickness of the arrows indicates the affinity of the ligands with the specific receptors. Particularly, IGF2 is locally produced by ACC cells, creating a loop that, associated with the overexpression of the IGF1R and IR, ${ }^{19,22,26}$ activates the IGF pathway. The most important downstream pathways are the phosphatidylinositol 3-kinase/active protein kinase $\mathrm{B}$ (PI3K/AKT) and mitogen-activated protein kinases/extracellular signal-regulated kinase (MAPK/ERK) cascade. ${ }^{17,}, 27,28$ The phosphorylation of AKT causes the activation of the mammalian target of rapamycin complex 1 (mTORC1), which phosphorylates two key effectors, p70S6 Kinase 1 (S6K1) and eukaryotic initiation factor 4E binding protein-1 (4EBP1), resulting in mRNA translation and regulation of several proteins involved in cell growth. $17,27,28$ AKT stimulates also cyclin D1, which promotes cell survival and phosphorylates the forkhead box O (FOXO), promoting cell division. Moreover, AKT inhibits $\mathrm{Bcl} 2$ antagonist of cell death (BAD) and activates the mouse double minute 2 (MDM2), preventing apoptosis, ${ }^{17,}, 27,28$ and, contrary to other cancer types, does not inhibit the phosphorylation of $\beta$-catenin by the glycogen synthase kinase-3b (GSK$3 b)$ in ACC. ${ }^{17,}, 29$ Thus, $\beta$-catenin can accumulate into cell nucleus and stimulates the transcription of Wnt target genes. The activation of the MAPK/ERK pathway through Shc, the growth factor receptor-bound protein 2 (Grb2) and Son of Sevenless (SOS), stimulates Ras to activate Raf, which phosphorylates the MAPK/ERK kinase (MEK)1/2 dual-specificity protein kinases. MEK1/2 activates ERK1/2 that has a major role in tumorigenesis and Jun amino-terminal kinases (JNK1/2/3), which translocate to the nucleus and regulate several transcription factors leading to cell proliferation. ${ }^{27,28}$ Finally, the activation of IR-A causes also the translocation of the glucose transporter type 4 (GLUT-4) to the cell membrane, increasing the cell glucose uptake. ${ }^{30} \mathrm{P}$ indicates major sites of phosphorylation. IGF-target agents used in ACC with corresponding targets are shown in boxes and are grouped as follow: anti-IGF1R antibodies (Ab) (cixutumumab, figitumumab, 1H7), IGF-1R tyrosine kinase (TK) inhibitor (NVP-AEW541), dual TK inhibitor of IGF1R and IR (linsitinib), mTOR inhibitors (sirolimus, temsirolimus), IGF2 neutralizing Ab and metformin, that decreases IGF2 and IGF1R expression, inhibits the phosphorylation of mTORC1 and MEK, in addition to reduce glucose and insulin blood levels.

tors A or B (hybrid-RA or hybrid-RB) according to the IR isoform. ${ }^{41}$ The ligand specificity, as well as the downstream signaling pathways, are determined by the IR isoform. Thus, hybrid-
RA binds all the three ligands (IGF1 and IGF2 with high affinity and insulin with low affinity) and activates the mitogenic signaling pathway, whereas hybrid-RB binds insulin and IGF1 and 
mediates the metabolic pathway. ${ }^{40-44}$ It has been shown that hybrid-RA are the most expressed receptors in some tissues ${ }^{45}$ and seem to be overexpressed also in some tumor cells, increasing the pool of receptors activating the mitogenic pathway. $40,42,44$ The binding of the ligand with its receptor causes the autophosphorylation of the tyrosine kinase subunit of IGF1R, IRA or hybridRA and the activation of numerous downstream pathways mediated by several proteins, among which the most important are the insulin receptor substrate (IRS1-6), the SRC homology and collagen (Shc) and the growth factor receptorbound protein 2 (Grb2). 27, 44, 46 The most critical downstream pathways in tumorigenesis are the phosphatidylinositol 3-kinase/active protein kinase $\mathrm{B}$ (PI3K/AKT) and mitogen-activated protein kinases/extracellular signal-regulated kinase (MAPK/ERK) cascade that are involved in cell proliferation, motility, survival, and antiapoptosis mechanisms (Figure 1).17, 27, 28 Briefly, the phosphorylation of AKT causes the activation of the mammalian target of rapamycin complex 1 (mTORC1), which results in the regulation of protein synthesis and cell growth, and of cyclin D1, which promotes cell survival. AKT inhibits $\mathrm{Bcl} 2$ antagonist of cell death (BAD) and activates the mouse double minute 2 (MDM2), preventing apoptosis, and phosphorylates the forkhead box O (FOXO), promoting cell division. ${ }^{17,} 27,28$ Differently from other cancer types, in ACT AKT does not inhibit the phosphorylation of $\beta$-catenin by the glycogen synthase kinase-3b (GSK3b). ${ }^{17,29}$ That lead to a decreased degradation of $\beta$-catenin that accumulates into cell nucleus and stimulates the transcription of Wnt target genes (Figure 1). The activation of the MAPK/ERK pathway through the Shc and other intracellular adaptor proteins, such as GRB2 and Son of Sevenless (SOS), lead to an increase of transcription factors and cell proliferation (Figure 1). ${ }^{27,}{ }^{28}$ Indeed, the binding of ligands to IGF1R/IR stimulates Ras to activate Raf, which phosphorylates the MAPK/ERK kinase (MEK)1/2 dual-specificity protein kinases. MEK1/2 activates four major terminal serine/threonine kinases, among which ERK1/2 that has a major role in tumorigenesis, and Jun amino-terminal kinases (JNK1/2/3).27, 28 Activated ERKs translocate to the nucleus where they phosphorylate gene, such as MYC, or regulate transcription factors, such as members of the ETS (E26 transformation-specific or E-twenty-six) family, leading to cell growth, survival and differentiation. Finally, the activation of IR causes also the translocation of the glucose transporter type 4 (GLUT-4) to the cell membrane, increasing the cell glucose uptake (Figure 1). ${ }^{30}$

In tumorigenesis, the IGF2R plays a minor role in comparison to IGF1R and IR, since it lacks the tyrosine kinase function and is not able to activate a signaling pathway. However, the IGF2R may present a tumor suppressor activity, through the internalization of IGF2 that can be degraded by lysosome, thus avoiding the binding with other receptors. ${ }^{25,}, 46$

Therefore, the overexpression of IGF2, often produced locally by tumor cells, ${ }^{47}$ as well as the overexpression of IGF1R and IRA observed in several tumor types, play a key role in tumorigenesis. ${ }^{32}$ Moreover, hybrid receptors may increase the pool of IGF system receptors and may provide a further growth advance in tumor cells. However, the role of hybrid-R is not completely understood and further studies are necessary to better investigate this receptor.

\section{The role of IGF system in normal adrenal glands}

The IGF system plays a crucial role in the embryogenesis and in the normal function of the adrenal glands. 18,48 In human fetal adrenal glands, the overexpression of the IGF2, mediated by $\mathrm{ACTH}$, induces the adrenal growth. 49,50 The expression of IGF1R, IGF2R and IR were observed in adult adrenal glands. ${ }^{19,} 26 \mathrm{An}$ immunohistochemical study showed a different distribution of IGF receptors along the adrenal cortex: the IGFR1 staining was more intense in the zona reticularis and glomerulosa, whereas IR staining was stronger in the zona fasciculate and reticularis. ${ }^{26}$ Contrary to this result, Weber et al. observed a similar expression of IGF1R e IR in the three zone of the adrenal cortex. ${ }^{19}$ However, the group of adrenal tissue samples investigated in this last study was significantly smaller than the previous one. ${ }^{19,} 26$ In-vitro studies in adrenocortical cells demonstrated that IGF1 and IGF2 stimulated the steroidogenesis, preferentially cortisol and androgen biosynthesis, through an upregula- 
tion of enzymes involved in the steroidogenesis and an upregulation of ACTH-receptors. ${ }^{51-53}$

The expression of the IGFBP 1-6 was demonstrated in fetal and adult adrenal glands where they regulate the steroidogenesis through a modulation of IGFs. ${ }^{51,54,55}$ It has been demonstrated that ACTH induces the expression of IGFBP-1 and -4 , whereas IGF1 and IGF2 stimulate the expression of IGFBP-3 and -5.51, 54, 55

\section{The IGF system in benign adrenocortical tumors}

No significant alterations of the IGF system were reported in benign ACT in comparison to normal adrenal glands. At the molecular levels, Ronchi et al. observed recurrent copy number (CN) gain in the chromosome region $11 \mathrm{p} 15.5$, including the IGF2 gene, in 6 out of 24 studied ACA (25\%). ${ }^{56}$ Moreover, the authors demonstrated no difference in IGF2 mRNA level between ACA and normal adrenal glands, independently from the genetic alterations. ${ }^{56}$ Normal IGF2 levels in ACA were also reported by other studies. ${ }^{57,58}$ However, Nielsen et al. did not find CN mutations of the $I G F 2$ locus in any of the 16 studied ACA, which were characterized by normal DNA methylation throughout this locus. ${ }^{58}$

As for $I G F 2$, no difference in IGF1 mRNA level was observed in ACA when compared with adrenal hyperplasia and normal adrenal glands. ${ }^{57}$ Similarly, De Fraipont et al. did not report high $I G F 1$ levels in all of the 18 ACA samples. ${ }^{59} \mathrm{At}$ the protein levels, IGF1 and its receptor IGF1R were only low expressed ${ }^{22,26}$ and IGF1R staining was similar compared to normal adrenal glands or adrenal hyperplasia. ${ }^{19}$ Barlaskar et al. investigated the activation of the IGF system through the evaluation of the phosphorylated IGF1R (pIGF1R) and the phosphorylated AKT (p-AKT) and they showed only a low or medium staining in ACA and normal adrenal glands in comparison to higher immunostaining in ACC, 20 indicating that IGF system was more activated in malignant tumors.

A very recent study showed that patients with non-functioning ACA $(\mathrm{N} .=50)$ had significantly higher circulating plasma IGF1 levels, even within the normal reference range, than the control group $(\mathrm{N} .=38) .{ }^{60}$ As previously reported, ${ }^{61,62}$ the Authors confirmed that $25 \%$ of patients af- fected by acromegaly, a disease characterized by high levels of IGF1, had ACA. ${ }^{60}$ This last finding indirectly indicated a role of IGF1 in the development of adrenal mass. Other indirect clinical evidence suggesting that IGF system plays a role in ACT development come from the increased frequency of insulin-resistant observed in patients with non-functioning ACA in comparison to healthy controls. ${ }^{63,}{ }^{64}$ Moreover, it has been shown that insulin sensitivity was inversely correlated with tumor size, ${ }^{64}$ speculating that insulin may play a role in the adrenal tumor growth. In support of this finding, Kamio et al. showed a high immunostaining of IR in a subgroup of 6 out $23 \operatorname{ACA}(26 \%) .26$

In conclusion, no significant differences in IGF2 mRNA level, IGF1 and IGF1R, at both mRNA and protein level, were observed in ACA compared to normal adrenal glands. ${ }^{56-58}$ Moreover, data regarding the $\mathrm{CN}$ gain in the $I G F 2$ gene were limited.56 Evidence coming from clinical studies suggests that circulating levels of IGF1 and insulin may be involved in the development and growth of adrenal masses. ${ }^{60,} 64$ However, data regarding the role of IR, as well as the expression of IRA and IRB in functioning and non-functioning ACA, together with the correlation with circulating insulin levels, are still missing.

The IGF system in adult adrenocortical carcinoma

Increased expression of IGF receptors and ligands has been observed in ACC and are summarized in Figure 1. The IGF2 overexpression is one of the most frequent molecular alteration in ACC, representing a hallmark of this cancer type. IGF 2 is overexpressed in more than $85 \%$ of cases $6,8,12,17,18,56,65,66$ and in ACC NCI-H295R cell line. ${ }^{67,68}$ The $I G F 2$ gene is located next to the insulin gene on chromosome $11 \mathrm{p} 15.5$ and together with $H 19$, composes the paradigmatic imprinting IGF2/H19 locus. ${ }^{58}$ Contrary to IGF2, H19 is downregulated in ACC in comparison to ACA. ${ }^{58}$ IGF2 transcription is regulated by genomic imprinting and is expressed from the paternal allele. ${ }^{47}$ Different mechanisms are involved in the $I G F 2$ overexpression. One of the most frequent event is somatic $\mathrm{CN}$ changes of the allele 
11p15.5, where loss of the maternal allele (loss of heterozygosity, LOH) is associated with paternal duplication of the $I G F 2 / H 19$ locus, resulting in a uniparental disomy-like genotype. ${ }^{56,58,69,70} \mathrm{It}$ has been demonstrated also a further allele loss $(\mathrm{LOH}+\mathrm{CN} \text { loss })^{56}$ as well as tetraploid state at IGF2/H19 locus 58 in a subgroup of ACC in two different studies. Both these further $\mathrm{CN}$ changes are associated with $I G F 2$ overexpression, without differences in $I G F 2$ level in comparison to LOH group. ${ }^{56,58}$ Another mechanism includes the hypermethylation of differentially methylated regions (DMR) of the IGF2/H19 locus: the IGF2 DMR0, the IGF2 DMR2 and the H19 DMR, which represents the imprinting control region (ICR) (containing seven CTCF binding sites), and the H19 promoter. ${ }^{30,71}$ Nielsen et al. showed hypermethylation of the H19 ICR (CTCF2, CTCF3, and CTCF6) and IGF2 DMR0 in ACC compared to ACA $(\mathrm{P}<0.0001$ and $\mathrm{P}=0.0067$, respectively), however they did not find any correlation between IGF2 expression and H19 ICR methylation status. ${ }^{58}$ It is interesting that the Authors demonstrated that $\mathrm{CN}$ changes of $11 \mathrm{p} 15.5$ allele correlated with hypermethylation of the H19 ICR, suggesting that the lost alleles were the unmethylated maternal alleles. This evidence suggests that the $I G F 2$ overexpression in ACC is due to the loss of the maternal allele and that hypermethylation of the H19 ICR is a consequence of this event. ${ }^{58}$ Contrary to what previously described by Nielsen, another study demonstrated that hypermethylation of DMR0, CTCF3, CTCF6 and H19 promoter were positively correlated with IGF2 mRNA level in ACC $(\mathrm{P}<0.05$ for all the region) and represented the most discriminant characteristic between ACC and ACA, with a sensitivity of $96 \%$ and specificity of $100 \% .^{72}$ These results were confirmed also in in vitro experiment in three different human ACC cell lines: NCI-H295R, SW13 and HAC15. The treatment of cells with the demethylating agent 5'-Aza-2'deoxycytidine (AZA) had the effect of strongly decrease the IGF2 mRNA level and increase the expression of H19.72 Thus, the Authors speculated that the DNA methylation is a strong regulatory element in IGF2/H19 expression.

However, the role of IGF2 in ACC tumorigenesis is still not completely clear. ${ }^{29,} 73$ Guillaud-
Betaille et al. showed that the inhibition of IGF2 with a small interfering RNA (siRNA) decreased the proliferation and increased the apoptosis in NCI-H295R cells. ${ }^{73}$ Moreover, transgenic mouse model overexpressing $I G F 2$ developed only adrenal hyperplasia of the zona fasciculata and not an ACT, demonstrating that IGF2 is not a tumor initiator but rather a factor of tumor progression that requires additional hits to trigger adrenal tumorigenesis. ${ }^{29,} 74$ Contrary to previous studies, which showed a more aggressive tumor phenotype associated with $I G F 2$ overexpression in a small cohort of patients, ${ }^{70,75}$ no differences in clinical, biological and transcriptomic characteristics were found in larger number of ACC patients who expressed high IGF2 level in comparison to those with low $I G F 2$ level. ${ }^{73}$ Only one study reported that high immunostaining of IGF2 correlated with longer OS in a small group of patients $(\mathrm{N} .=20) .{ }^{76}$ Moreover, since its high prevalence in ACC, IGF2 overexpression could not be useful for the classification of ACC derived by transcriptome analyses. ${ }^{12}$

Different studies demonstrated no differences in IGF1 mRNA level between ACC and ACA or normal adrenal gland. 57, 59, 77 Particularly, the recent TCGA Study reported IGF1 mRNA upregulation only in $16 \%$ of the included ACC. 8 A single immunohistochemical study by Kamio et al. described high or medium IGF1 staining in $33 \%$ and $39 \%$, respectively, of ACC samples in comparison to $4 \%$ and $17 \%$, respectively, of ACA tissues. ${ }^{26}$

Regarding the IGF1R, it has been demonstrated an upregulation at mRNA level only in approximately $4 \%$ of a recent ACC series. ${ }^{8}$ However, several studies showed high staining of IGF1R in ACC tissues. ${ }^{19,}$ 22, 26 Kamio et al., which investigated the largest series of ACT samples for the evaluation of IGF1, IGF1R and IR by immunohistochemistry, observed medium and high IGF1R staining in $42 \%$ and $29 \%$, respectively, of ACC samples in comparison to $17 \%$ and $4 \%$, respectively, of ACA samples. ${ }^{26}$ In a more recent study, Xu et al. showed a high IGF1R staining in $80 \%$ of the studied ACC tissue samples. 22

The overexpression of IGF2, produced locally by ACC cells, creates an auto-paracrine loop that 
sustains cancer cells proliferation through the activation of the IGF1R and of its downstream effector AKT (Figure 1). In two ACC cell lines, NCI-H295R and SW13, it has been demonstrated that high expression of the active form of IGF1R, the p-IGF1R, correlated with increased levels of p-AKT. 20, 68 Barlaskar et al. observed significant increased expression of $\mathrm{p}$-IGF1R and $\mathrm{p}$-AKT in ACC samples in comparison to ACA and normal adrenal tissues. ${ }^{20}$ Particularly, the Authors showed a medium-high staining of p-IGF1R in $75 \%$ of ACC vs. $30 \%$ of ACA and $25 \%$ of normal adrenals, and a medium-high staining of p-AKT in $30 \%$ of ACC in comparison to $0 \%$ of both ACA and normal adrenals. ${ }^{20}$ In a previous study, Fassnacht et al., although they observed a significant increase of total AKT in ACC, did not find an increase of $\mathrm{p}$-AKT/AKT ratio. ${ }^{78}$ Moreover, they described areas of strong $\mathrm{p}$-AKT staining in ACC tissues by immunohistochemistry analysis, indicating a local activation of the IGF pathway. The Authors speculated that the impairment of the IGF system may be relevant only in a subgroup of selected patients. ${ }^{78}$

Only one study investigated the expression of IR in ACT. Kamio et al. showed a stronger intensity of IR in ACC in comparison to ACA and no correlation between IR expression and pathological parameters. ${ }^{26}$ To the best of our knowledge, there no study which investigated the expression of IR isoforms in ACT.

In in-vitro studies, it has been shown that IGFBP-2 levels were increased in NCI H295R cell line ${ }^{67}$ and that the treatment with antibody against IGFBP-2 reduced cells proliferation.79 This finding was confirmed also in ACC patients, where high circulating plasma level of IGF-BP2 were associated with malignant phenotype ${ }^{75}$ and metastases. ${ }^{80}$

In summary, the most relevant alteration of the IGF pathway in ACC is the overexpression of IGF2 that is over-product locally by the tumor cells, due to different genetic alterations. 6, 8, 12, 17, 18, 56, 65, 66 This creates an auto-paracrine positive loop that, associated with the overexpression of the IGF1R and IR, 19, 22, 26 activates the IGF pathway stimulating tumor cells proliferation and antiapoptotic mechanisms (Figure 1). This pathway could be additionally activated by the potential overexpression of IR; however, studies are needed to better investigate IR isoforms in ACC.

The IGF system in pediatric adrenocortical carcinoma

The alteration of the IGF system is also observed in pediatric ACC. As for adult ACC, several studies showed $\mathrm{CN}$ changes of the allele $11 \mathrm{p} 15.5$ associated with $I G F 2$ overexpression that not correlated with tumor recurrence or clinical outcome. ${ }^{66,81-83}$ It has been demonstrated an overexpression of IGFIR in pediatric ACC in comparison to $\mathrm{ACA}^{66,84}$ and that, differently from adult ACC, correlated with a higher risk to develop metastases. ${ }^{66}$ A more recent study, even though did not find differences in IGFIR levels between pediatric ACC and normal adrenal glands, showed that the $I G F 1 R$ expression correlated with the disease status and that $I G F 1 R$ was overexpressed in patients with relapse or metastases. ${ }^{82}$ Moreover, the Authors did not report a correlation between mRNA and protein levels for both IGF2 and IGF1R. They also described a prevalent cytoplasmic localization of IGF1R without prognostic relevance, ${ }^{82}$ as already demonstrated in other cancer types. ${ }^{85}$

To the best of our knowledge, evidence regarding the expression of other members of the IGF system in pediatric ACC is still missing.

\section{Targeting the IGF system in ACC}

Evidence of aberrant expression of the IGF system in several tumor cells and cancer types encouraged the development of many IGF1R-target molecules which are summarized in Figure 1. Preclinical studies that used these molecules for the treatment of ACC cell lines showed promising results. ${ }^{17}$ An in-vitro study in NCI-H295R cells established that the downregulation of IGF1R through a specific siRNA decreased cell growth and increased apoptosis of $40 \%$ and $45 \%$, respectively. ${ }^{86}$ Similar results were also obtained from others in-vitro studies. Almeida et al. showed that the treatment of NCI-H295R and pediatric ACT cell lines deriving from a functional ACA, with a selective IGF-1R tyrosine kinase (TK) inhibitor (NVP-AEW541), had antitumor effects in 
both cell lines. ${ }^{66}$ The NVP-AEW541 showed to cause an inhibition of cell proliferation in a doseand time-dependent manner through a significant increase of apoptosis. ${ }^{66}$ Barlaskar et al. reported that the treatment with IMC-A12, a monoclonal antibody targeting the IGF1R (cixutumumab), or with the TK inhibitor NVP-AEW541 reduced NCI-H295R cell proliferation both in vitro and in vivo in mouse xenograft model. ${ }^{20}$ However, these molecules targeting only the IGF1R may create resistance to treatment due to the possible presence of IR-A on tumor cells membranes that can promote tumor progression. ${ }^{25}$ It has been demonstrated a bidirectional cross talk in tumor cells coexpressing IGF1R and IR, and the treatment with a selected IGF1R inhibitor resulted in a compensatory increase in phospho-IR (p-IR), with consequent activation of the downstream pathway. ${ }^{87}$ Moreover, it has been shown that the resistance to cixutumumab was conferred by the IR isoforms, where IR-A overexpression conferred complete resistance to this treatment both in vitro and in vivo in lung adenocarcinoma. ${ }^{8} 8$ This mechanism might be extended to other IGF inhibitors and to other cancer types, including ACC. To avoid the resistance to IGF1R inhibitors, dual-targeting of IGF1R and IR have been developed. In-vitro experiments in NCI-H295R cells demonstrated that the treatment with OSI906 (linsitinib), a dual TK inhibitor, upregulated caspases activities and apoptosis, inducing cell cycle arrest and consequent reduction of cell viability in dose-dependent manner. ${ }^{82}$ Moreover, linsitinib inhibited also the expression of genes involved in steroidogenesis, including the steroidogenic acute regulatory (STAR) gene, leading to a reduction in testosterone secretion. ${ }^{82}$

However, clinical trials using these inhibitors reported disappointing results (Table I).23, 24, 89-92 In a phase I trial, investigating the safety and efficacy of figitumumab, an IGF1R monoclonal antibody, in 14 patients with advanced ACC, the best objective response according to RECIST (Response Evaluation Criteria in Solid Tumors) criteria was a stable disease in $60 \%$ of patients for a short time and the most common adverse event was hyperglycemia (Table I).23 Another phase I study by Jones et al. evaluating the safety, pharmacokinetics and pharmacodynamics of the dual TK inhibitor linsitinib in advanced solid tumors, among which ACC, showed a stable disease only in 2 out 15 patients $(13 \%)$ affected by ACC (Table I). ${ }^{91}$ Also in this study, the most common reported adverse event was hyperglycemia, ${ }^{91}$ due to the cross-reactivity of linsitinib with IR-B. ${ }^{93}$ Disappointing results were also obtained in a multicenter, randomized, double-blind, placebo-controlled phase III trials using linsitinib (NCT00924989; Table I). ${ }^{24}$ In this study were enrolled 139 patients with progressive ACC after first-line standard treatment, of whom 90 were assigned to linsitinib group, and 49 were assigned to placebo group. At the end of the study, no differences in OS and median progressive-free survival (PFS) were observed between the two groups. According to RECIST criteria, none achieved complete response, whereas 3 patients $(3 \%)$ treated with linsitinib presented a partial response. ${ }^{24}$ The treatment with linsitinib was well tolerated, and the most common adverse events were fatigue and gastrointestinal toxicities. ${ }^{24}$ Similar to adult $\mathrm{ACC}$, also in pediatric tumor the treatment with inhibitors of IGF system showed disappointing results. A phase II study (NCT00831844) carried out in advanced solid tumors, among which 10 recurrent ACC ( 8 pediatric and 2 adult), showed a progressive disease in all ACC patients treated with cixutumumab (Table I). ${ }^{90}$

Results deriving from clinical trials demonstrated that the single inhibition of the IGF1R/ IR signaling is not sufficiency to improve the OS and PFS in ACC patients, suggesting to look into new alternative combination therapies that inhibit more than one pathway. An in-vitro study showed that the treatment with IGF2-neutralizing antibody and sirolimus, a mammalian target of rapamycin (mTOR) inhibitor, was able to block of $90 \%$ NCIH295R cells proliferation compared to $64 \%$ and $42 \%$ with sirolimus or anti-IGF2 antibody alone, respectively. ${ }^{94}$ A recent study in NCI-H295R and SW13 cell lines and mouse xenograft model investigated the effects of combination therapy with the TK inhibitor NVP-AEW541 and erlotinib, an inhibitor of the epidermal growth factor receptor (EGFR). ${ }^{22}$ The combination therapy with NVPAEW541 and erlotinib showed enhanced antitumor efficacy compared to either molecule alone, inducing apoptosis in vitro and inhibiting the tu- 
mor growth in vivo by blocking the phosphorylation of both AKT and MEK/ERK. ${ }^{22}$ Another interesting in vivo study investigated the efficacy of liposomal doxorubicin associated with an IGF1R antibody $(1 \mathrm{H} 7)$ in cell-derived NCI-H295R and tissue-derived SJ-ACC3 and MUC-1 xenografts mouse models. ${ }^{21}$ The Authors used three different therapeutic approaches: the scheme with liposomal doxorubicin + free anti IGF1R antibody $1 \mathrm{H} 7$ $(\mathrm{L}+\mathrm{Ab})$, the scheme with anti IGF1R targeted doxorubicin loaded immunoliposomes (IL) and injection of sodium chloride as control. They showed that both $\mathrm{L}+\mathrm{Ab}$ and IL schemes caused a significant reduction in tumor size and higher rates of complete or partial remission in mouse after long-term treatment. ${ }^{21}$ However, only few clinical studies investigated the combination of IGF1R/IR inhibitors with other anticancer treatment. A phase I trial in advanced solid tumors, including $10 \mathrm{ACC}$ patients, reported a stable disease for more than 8 months in $40 \%$ of ACC patients ( 4 out 10 ) treated with the combination of cixutumumab and temsirolimus, an mTOR inhibitor (Table I). ${ }^{92}$ However, no one of these patients reported complete or partial response to therapy. ${ }^{92}$ The combination therapy with cixutumumab and mitotane presented limited efficacy (NCT00778817), with a median PFS of 6 weeks (range: 2.66-48). ${ }^{89}$ Only one patient out of 15 $(6.7 \%)$ presented partial response according to RECIST criteria, whereas 7 patients $(46.7 \%)$ had a stable disease as best response (Table I). ${ }^{89}$

Another drug that interferes with the IGF1R/ IR pathway in tumor cells is metformin, ${ }^{95} \mathrm{a}$ biguanide commonly used in the treatment of type 2 diabetes mellitus (T2DM) as an insulin-sensitized and glucose-lowering medicament. Epidemiological studies have been reported a significant association between metformin and reduced cancer risk in patients with T2DM, as well as in vivo and in-vitro studies have been shown that metformin has a direct antitumor effect. $95,96 \mathrm{Re}-$ cently, Poli et al. demonstrated in vitro and in vivo the antiproliferative effect of metformin in ACC NCI-H295R cells and mouse xenograft model. ${ }^{97}$ The Authors showed that metformin treatment in vitro significantly reduced cell proliferation and viability in a dose- and time-dependent manner, inhibited ERK1/2 and mTOR phosphorylation/ activation, and stimulated the apoptotic pathway. ${ }^{97}$ Moreover, metformin treatment decreased the expression of IGF2 and IGF1R in ACC cells, interfering with the proliferative autocrine loop of IGF2/IGF-1R, which supported tumor growth. In vivo, metformin administration inhibited tumor growth with a significant reduction of $\mathrm{Ki} 67 \%$ in tumor tissues. ${ }^{97}$ In support to these findings, a case report described a complete clinical remission of 7 years from diagnosis of a 31-year-old female patient affected by advanced ACC resistant to standard chemotherapy and treated with metformin (500 mg twice daily) and melatonin (20 mg daily) as personalized therapy, as suggested by the morphoproteomic analysis. ${ }^{98}$ Interesting is the fact that the morphoproteomic analysis derived from the lung metastasis with the patient on maintenance treatment showed molecular evidence of growth inhibition (reduced Ki67\% and mitotic index) in comparison to the analysis performed before start the treatment. 98 The complete remission presented by this patient supports the potential role of metformin as anticancer drug also in ACC as already showed in other tumor types. $46,95,96$

This last case report indicates also the relevance to a personalized medicine that allows to select patients who could better respond to a specific treatment. Indeed, it is important to note that one of the lack in these studies is that the Authors did not use predictive markers that could be useful for the response to treatment, such as the evaluation of IGF1R or IR expression, before selecting patients and starting the treatment. Moreover, the concomitant inhibition of more than one pathway seems to be more promising in reducing cell proliferation and prolonging PFS in patients affected by ACC. Thus, studies that investigate predictive markers for the response of IGF1R/IR inhibitors and further clinical studies evaluating the combination of more molecules, are urgently needed.

\section{Evidence synthesis}

The results of this review can be summarized as follows:

- the IGF system plays a major role in the regulation of different biological functions of the 
TABLE I.-Published clinical studies and trials with drug targeting IGF system in patients with advanced adrenocortical carcinoma.

\begin{tabular}{|c|c|c|c|c|}
\hline $\begin{array}{l}\text { ClinicalTrials.gov } \\
\text { identifier or local } \\
\text { Ethic Committee }\end{array}$ & Dose intervention & Target & Phase & Population \\
\hline NCT00924989 & OSI-906 $150 \mathrm{mg}$ twice daily orally $v s$. placebo. & IGF1R + IR & III & $\begin{array}{l}\text { Locally advanced, metastatic } \\
\text { ACC (N.=139; } 90 \text { treated } \\
\text { with OSI-906 and } 49 \text { with } \\
\text { placebo). }\end{array}$ \\
\hline NCT00778817 & $\begin{array}{l}\text { Mitotane + IMC-A } 12 \text { was dosed at } 10 \mathrm{mg} / \mathrm{kg} \\
\text { intravenously every } 2 \text { weeks. Due to slow } \\
\text { accrual, the study was terminated before the } \\
\text { randomization phase and became a single-arm } \\
\text { study. }\end{array}$ & IGF1R + mitotane & II & $\begin{array}{l}\text { Recurrent, metastatic, or } \\
\text { primary unresectable ACC } \\
(\mathrm{N} .=20) \text {. }\end{array}$ \\
\hline NCT00831844 & $\begin{array}{l}\text { Cixutumumab dosed at } 9 \mathrm{mg} / \mathrm{kg} / \text { dose IV over } \\
1 \text { hour on days } 1,8,15 \text {, and } 22 \text {. Treatment } \\
\text { repeats every } 28 \text { days for up to } 24 \text { courses. }\end{array}$ & IGF1R & II & $\begin{array}{l}\text { Solid tumors and recurrent } \\
\text { ACC (Group 4; N.=10 of } \\
\text { whom } 8 \text { were pediatric). }\end{array}$ \\
\hline $\begin{array}{l}\text { Local Ethic } \\
\text { Committee }\end{array}$ & $\begin{array}{l}\text { Once-daily OSI-906, schedule (S) } 1 \text {, days } 1-3 \\
\text { every } 14 \text { days; S2, days } 1-5 \text { every } 14 \text { days; S3, } \\
\text { days } 1-7 \text { every } 14 \text { days }\end{array}$ & IGF1R + IR & I & $\begin{array}{l}\text { Advanced solid tumors, } \\
\text { among which ACC }\left(\mathrm{N}_{.}=15 \text {; }\right. \\
9 \text { in } \mathrm{S} 1,1 \text { in } \mathrm{S} 2 \text { and } 5 \text { in } \mathrm{S} 3) .\end{array}$ \\
\hline $\begin{array}{l}\text { Local Ethic } \\
\text { Committee }\end{array}$ & $\begin{array}{l}\text { Four dose cohorts with escalating doses of } \\
\text { temsirolimus ( } 25 \text { to } 37.5 \mathrm{mg} \text { ) and cixutumumab } \\
\text { ( } 3 \text { to } 6 \mathrm{mg} / \mathrm{kg} \text { ) weekly for } 28 \text { days. }\end{array}$ & IGF1R + mTOR & I & $\begin{array}{l}\text { Advanced solid tumors, } \\
\text { among which ACC }(\mathrm{N} .=10)\end{array}$ \\
\hline $\begin{array}{l}\text { Local Ethic } \\
\text { Committee }\end{array}$ & Figitumumab $20 \mathrm{mg} / \mathrm{kg}$ IV, every 21 days. & IGF1R & I & $\begin{array}{l}\text { Metastatic, refractory ACC } \\
(\mathrm{N} .=14) \text {. }\end{array}$ \\
\hline
\end{tabular}

ACC: adrenocortical carcinoma; N.: number of patients; IGF1R: insulin-like growth factor 1 receptor; IR: insulin receptor; IV: intravenously; MTD: maximum tolerated dose; mTOR: mammalian target of rapamycin; OS: overall survival; PFS: progression-free survival; PD: progressive disease; PR: partial response; SD: stable disease.

adrenal gland and is one of the most frequently altered pathways in $\mathrm{ACC} ;{ }^{17}$

- in fetal adrenal glands, the overexpression of the IGF2 induces the adrenal growth, 49,50 whereas, in adult adrenal glands, both IGF1 and IGF2 stimulate the steroidogenesis in vitro;51-53

- no significant alterations of the IGF system were observed in ACA in comparison to normal adrenal glands. ${ }^{56-58}$ However, circulating IGF1 and insulin may play a role in adrenal tumor growth; 60,64

- in ACC, the IGF2 overexpression, is one of the most frequent molecular alterations (more than $85 \%$ of cases). $6,8,12,17,18,56,65,66$ Different mechanisms are involved in the IGF2 overexpression, including the somatic $\mathrm{CN}$ changes of the allele $11 \mathrm{p} 15.5$, with the $\mathrm{LOH}$ of the maternal allele, 56, 58, 69, 70 and the hypermethylation of DMR of the $I G F 2 / H 19$ locus; 58,72

- IGF1 seems to be high expressed only in a subgroup of ACC patients, ${ }^{8,} 26$ whereas several studies showed high staining of IGF1R in ACC tissues. ${ }^{19,22,26}$ Different studies found also an activation of the IGF pathway in both cell lines and ACC patients through the demonstration of high levels of p-IGF1R and p-AKT;20, 68, 78
- data regarding the IR expression are scant, and only one study showed a stronger intensity of IR in ACC in comparison to ACA; 26

- the alteration of the IGF system is also observed in pediatric ACC, mainly characterized by $I G F 2$ overexpression. ${ }^{66,81-83}$ Differently from adult $\mathrm{ACC}$, in pediatric $\mathrm{ACC}$ the overexpression of $I G F I R$ is more evident 66,84 and correlates with advanced disease; 66,82

- preclinical studies using inhibitors of the IGF system (antibody targeting the IGF1R, TK inhibitor, or the dual-targeting of the IGF1R and IR) reduced ACC cells proliferation both in vitro and in vivo. $20,66,86$ However, these promising results were not confirmed in clinical trials. 23,24 Better results were observed in preclinical studies investigating the effects of these agents with other types of anticancer therapy;21,94

- an in-vitro study suggested the potential antitumor activity of metformin in ACC cells. ${ }^{97}$ Clinical studies are necessary to validate that.

\section{Conclusions}

The pathophysiology underlying the molecular mechanisms involved in the ACT development is 


\begin{tabular}{|c|c|c|}
\hline Primary outcome & Results & References \\
\hline $\begin{array}{l}\text { Overall survival of single agent OSI-906 versus } \\
\text { placebo. }\end{array}$ & $\begin{array}{l}\text { No differences in OS and PFS between the two } \\
\text { groups. 3/90 patients had PR. }\end{array}$ & Fassnacht et al. ${ }^{24}$ \\
\hline PFS rate. & $\begin{array}{l}\text { Median PFS was } 6 \text { weeks (range } 2.66-48 \text { ). Best } \\
\text { response rate in } 15 \text { patients: } 1 \text { PR, } 7 \text { SD, } 8 \text { PD. }\end{array}$ & Lerario et al. ${ }^{89}$ \\
\hline $\begin{array}{l}\text { Response rate to cixutumumab and further } \\
\text { toxicities. }\end{array}$ & $\begin{array}{l}10 / 10 \text { had PD or interrupted treatment due to } \\
\text { adverse events ( } 1 \text { death for the disease). }\end{array}$ & Weigel et al. ${ }^{90}$ \\
\hline $\begin{array}{l}\text { MTD, safety, pharmacokinetics, } \\
\text { pharmacodynamics, and activity of OSI-906. }\end{array}$ & $\begin{array}{l}\text { The MTD was } 600 \mathrm{mg} \text { and associated with } \\
\text { antitumor activity. } \\
2 \mathrm{SD}(\mathrm{S} 1), 13 \mathrm{PD} \text {. }\end{array}$ & Jones et al. ${ }^{91}$ \\
\hline $\begin{array}{l}\text { Safety and tolerability. Tumor response as } \\
\text { secondary outcome. }\end{array}$ & $\begin{array}{l}\text { Treatment well tolerated. MTD was cixutumumab } \\
6 \mathrm{mg} / \mathrm{kg} \text { IV + temsirolimus } 25 \mathrm{mg} \text { IV weekly. } \\
4 / 10 \text { patients had SD for more than } 8 \text { months. }\end{array}$ & Naing et al. ${ }^{92}$ \\
\hline $\begin{array}{l}\text { Safety, tolerability, pharmacokinetics, and efficacy } \\
\text { of figitumumab. }\end{array}$ & $\begin{array}{l}8 / 14 \text { SD for short time, } 6 / 14 \mathrm{PD} \text { or interrupted the } \\
\text { treatment due to adverse events. }\end{array}$ & Haluska et al. ${ }^{23}$ \\
\hline
\end{tabular}

still not entirely clear, despite the several genomics studies published in the last decades. ${ }^{7-11}$ In comparison to ACA, ACC showed deregulation of several signaling pathway, among which the IGF system is one of the most frequently altered, even though it plays also a significant role in the regulation of different biological functions in the normal adrenal gland. ${ }^{17,18}$

In summary, ACC demonstrated overexpression of two critical components of the IGF system, the IGF26, 8, 12, 17, 18 and the IGF1R, 19, 22, 26 whereas only one study reported a strong immune-staining of IR. ${ }^{26}$ Thus, IGF2 creates an auto-paracrine loop that stimulates the activation of the IGF1R and IR and the concomitant phosphorylation of its downstream effector, AKT, sustaining tumor growth.

For these reasons, the targeting of the IGF represents a promising treatment approach in ACC patients. ${ }^{17}$ This encouraged several preclinical studies which used antibody targeting the IGF1R (cixutumumab) or TK inhibitor of IGF1R (NVPAEW541) with promising results $20,25,66$ that were not confirmed in clinical studies. ${ }^{23,91}$ These disappointing results could be explained by a cross-talk between IGF1R and IR that causes a compensatory increase in $\mathrm{p}-\mathrm{IR}$ when tumor cells are treated with a selected IGF1R inhibitor. ${ }^{87}$ Moreover, in tumor cells that coexpressed both IGF1R and IR-A, the IGF1R inhibition upregulates IR-A, reducing the inhibition of the downstream pathway and contributing to resistance to IGF1R-target therapy. 88,93 Indeed, these agents are not able to inhibit the activation of IR-A and Hybrid-RA by IGF2.93

To avoid this resistance, a dual-targeting of IGF1R and IR have been used (OSI-906). However, the only phase III randomized, clinical trials investigating the administration of this compound in a large cohort of ACC patients, showed a partial response only in $3 \%$ of patients. ${ }^{24}$ This disappointing results observed in clinical trials can arise from the crosstalk between the IGF1R/ IR and other TK receptors, including the epithelial growth factor receptor (EGFR), the vascular endothelial growth factor receptor (VEGFR), the mesenchymal epithelial transition factor (cMET), the human epidermal growth factor receptor 2 (HER2), the plated-derived growth factor receptor (PDGFR) and steroid hormone receptors. ${ }^{93}$ Therefore, the combination of IGF1R/IR inhibitors with other anticancer agents may represent a more clinically effective treatment approach. However, to choose the potential 
most effective combination treatment, preclinical studies are needed to better investigate the crosstalk between IGF1R and IR with other TK receptors in ACC.

The major weakness of these studies is that the Authors did not use predictive markers, such as the evaluation of IGF1R or IR expression in tumor tissues, that could be useful for select patients who could better response to IGF-target treatment. Therefore, the evaluation of potential predictive markers should be performed before starting the treatment with these agents to better select patients, allowing to go toward a personalized medicine.

A still open question is the potential role of IR-A in adrenocortical tumorigenesis. Indeed, to the best of our knowledge, there are no studies that investigate the expression of IR isoforms in ACT. This is an important point, since the IR-A overexpression, together with the consequent formation of Hybrid-RA, may increase the pool of IGF system receptors providing a further growth advance in tumor cells, as already showed in other tumor types. ${ }^{39}$ Moreover, IR-A could be used as a predictive marker of intrinsic resistance to IGF1R inhibitors also in ACC. 88

Another open question is the efficacy of the dual-targeting of IGF1R and IR, which represent the more promising inhibitor of the IGF system. Stronger evidence to support the inhibition by these molecules of the IR-A, as well as the of Hybrid-IR, are needed. Moreover, clinical studies in ACC patients evaluating the efficacy of these agents associated with other anticancer treatment, selected by molecular and genetic profile of each patient toward a personalized medicine, are urgently needed.

A final open question, but not less important, is the antitumor activity of metformin in ACC patients. To the best of our knowledge, there are no studies that investigate ACC prevalence and metformin treatment in patients with T2DM. Metformin interferes with the proliferative autocrine loop of IGF2/IGF-1R in vitro, and inhibited tumor growth in vivo, ${ }^{97}$ and a case report demonstrated the efficacy of this drug. ${ }^{98}$ Moreover, metformin reduces also insulin and glucose blood levels, which may play a role in the adrenal tumor cells growth and metabolism. Due to the aggressiveness of the disease and the limited response to standard therapy, new treatment options are urgently needed. A new future therapeutic approach may be represented by metformin that may be associated to standard therapy, such as mitotane. However, preclinical studies, investigating the combination of metformin with other treatment, and clinical studies, investigating the potential efficacy of metformin, are necessary to confirm its antitumor activity in ACC.

\section{References}

1. Fassnacht M, Arlt W, Bancos I, Dralle H, Newell-Price J, Sahdev A, et al. Management of adrenal incidentalomas: $\mathrm{Eu}-$ ropean Society of Endocrinology Clinical Practice Guideline in collaboration with the European Network for the Study of Adrenal Tumors. Eur J Endocrinol 2016;175:G1-34.

2. Fassnacht M, Kroiss M, Allolio B. Update in adrenocortical carcinoma. J Clin Endocrinol Metab 2013;98:4551-64.

3. Kerkhofs TM, Verhoeven RH, Van der Zwan JM, Dieleman J, Kerstens MN, Links TP, et al. Adrenocortical carcinoma: a population-based study on incidence and survival in the Netherlands since 1993. Eur J Cancer 2013;49:2579-86.

4. Fassnacht M, Libé R, Kroiss M, Allolio B. Adrenocortical carcinoma: a clinician's update. Nat Rev Endocrinol 2011;7:323-35.

5. Else T, Kim AC, Sabolch A, Raymond VM, Kandathil A, Caoili EM, et al. Adrenocortical carcinoma. Endocr Rev 2014;35:282-326.

6. Faillot S, Assie G. ENDOCRINE TUMOURS: the genomics of adrenocortical tumors. Eur $\mathrm{J}$ Endocrinol 2016; 174:R249-65.

7. Assié G, Letouzé E, Fassnacht M, Jouinot A, Luscap W, Barreau $\mathrm{O}$, et al. Integrated genomic characterization of adrenocortical carcinoma. Nat Genet 2014;46:607-12.

8. Zheng S, Cherniack AD, Dewal N, Moffitt RA, Danilova L, Murray BA, et al.; Cancer Genome Atlas Research Network. Comprehensive Pan-Genomic Characterization of Adrenocortical Carcinoma. Cancer Cell 2016;29:723-36.

9. Jouinot A, Assie G, Libe R, Fassnacht M, Papathomas T, Barreau $\mathrm{O}$, et al. DNA Methylation Is an Independent Prognostic Marker of Survival in Adrenocortical Cancer. J Clin Endocrinol Metab 2017;102:923-32.

10. Ronchi CL, Di Dalmazi G, Faillot S, Sbiera S, Assié G, Weigand I, et al.; European Network for the Study of Adrenocortical Tumors (ENSAT). Genetic Landscape of Sporadic Unilateral Adrenocortical Adenomas Without PRKACA p.Leu206Arg Mutation. J Clin Endocrinol Metab 2016;101:3526-38.

11. Giordano TJ, Thomas DG, Kuick R, Lizyness M, Misek $\mathrm{DE}$, Smith AL, et al. Distinct transcriptional profiles of adrenocortical tumors uncovered by DNA microarray analysis. Am J Pathol 2003;162:521-31.

12. Bonnet-Serrano F, Bertherat J. Genetics of tumors of the adrenal cortex. Endocr Relat Cancer 2018;25:R131-52.

13. Altieri B, Sbiera S, Della Casa S, Weigand I, Wild V, Steinhauer S, et al. Livin/BIRC7 expression as malignancy marker in adrenocortical tumors. Oncotarget 2017;8:9323-38. 
14. Ronchi CL, Sbiera S, Altieri B, Steinhauer S, Wild V, Bekteshi M, et al. Notch1 pathway in adrenocortical carcinomas: correlations with clinical outcome. Endocr Relat Cancer 2015;22:531-43

15. Muscogiuri G, Altieri B, Penna-Martinez M, Badenhoop $\mathrm{K}$. Focus on vitamin D and the adrenal gland. Horm Metab Res 2015;47:239-46.

16. Tirabassi G, Salvio G, Altieri B, Ronchi CL, Della Casa S, Pontecorvi A, et al. Adrenal disorders: is there Any role for vitamin D? Rev Endocr Metab Disord 2017;18:355-62.

17. Altieri B, Tirabassi G, Della Casa S, Ronchi CL, Balercia $\mathrm{G}$, Orio F, et al. Adrenocortical tumors and insulin resistance: what is the first step? Int J Cancer 2016;138:2785-94.

18. Fottner C, Hoeflich A, Wolf E, Weber MM. Role of the insulin-like growth factor system in adrenocortical growth control and carcinogenesis. Horm Metab Res 2004;36:397-405.

19. Weber MM, Auernhammer CJ, Kiess W, Engelhardt D. Insulin-like growth factor receptors in normal and tumorous adult human adrenocortical glands. Eur J Endocrinol 1997;136:296-303.

20. Barlaskar FM, Spalding AC, Heaton JH, Kuick R, Kim AC, Thomas DG, et al. Preclinical targeting of the type I insulin-like growth factor receptor in adrenocortical carcinoma. J Clin Endocrinol Metab 2009;94:204-12.

21. Beuschlein F, Jakoby J, Mentz S, Zambetti G, Jung S, Reincke M, et al. IGF1-R inhibition and liposomal doxorubicin: progress in preclinical evaluation for the treatment of adrenocortical carcinoma. Mol Cell Endocrinol 2016;428:82-8.

22. Xu L, Qi Y, Xu Y, Lian J, Wang X, Ning G, et al. Coinhibition of EGFR and IGF1R synergistically impacts therapeutically on adrenocortical carcinoma. Oncotarget 2016;7:36235-46.

23. Haluska P, Worden F, Olmos D, Yin D, Schteingart D, Batzel GN, et al. Safety, tolerability, and pharmacokinetics of the anti-IGF-1R monoclonal antibody figitumumab in patients with refractory adrenocortical carcinoma. Cancer Chemother Pharmacol 2010;65:765-73.

24. Fassnacht M, Berruti A, Baudin E, Demeure MJ, Gilbert $\mathrm{J}$, Haak H, et al. Linsitinib (OSI-906) versus placebo for patients with locally advanced or metastatic adrenocortical carcinoma: a double-blind, randomised, phase 3 study. Lancet Oncol 2015; 16:426-35.

25. Bowers LW, Rossi EL, O'Flanagan $\mathrm{CH}$, deGraffenried LA, Hursting SD. The Role of the Insulin/IGF System in Cancer: Lessons Learned from Clinical Trials and the Energy Balance-Cancer Link. Front Endocrinol (Lausanne) 2015;6:77.

26. Kamio T, Shigematsu K, Kawai K, Tsuchiyama H. Immunoreactivity and receptor expression of insulinlike growth factor I and insulin in human adrenal tumors. An immunohistochemical study of 94 cases. Am J Pathol 1991;138:83-91.

27. Iams WT, Lovly CM. Molecular Pathways: Clinical Applications and Future Direction of Insulin-like Growth Factor-1 Receptor Pathway Blockade. Clin Cancer Res 2015;21:4270-7.

28. Tao Y, Pinzi V, Bourhis J, Deutsch E. Mechanisms of disease: signaling of the insulin-like growth factor 1 receptor pathway - therapeutic perspectives in cancer. Nat Clin Pract Oncol 2007;4:591-602.

29. Drelon C, Berthon A, Ragazzon B, Tissier F, Bandiera R, Sahut-Barnola I, et al. Analysis of the role of Igf2 in adrenal tumour development in transgenic mouse models. PLoS One 2012;7:e44171.

30. Nyman E, Cedersund G, Strålfors P. Insulin signaling - mathematical modeling comes of age. Trends Endocrinol Metab 2012;23:107-15.
31. LeRoith D, Roberts CT Jr. The insulin-like growth factor system and cancer. Cancer Lett 2003;195:127-37.

32. Vigneri R, Goldfine ID, Frittitta L. Insulin, insulin receptors, and cancer. J Endocrinol Invest 2016;39:1365-76.

33. Frasca F, Pandini G, Sciacca L, Pezzino V, Squatrito S, Belfiore A, et al. The role of insulin receptors and IGF-I receptors in cancer and other diseases. Arch Physiol Biochem 2008; 114:23-37.

34. Clemmons DR. Modifying IGF1 activity: an approach to treat endocrine disorders, atherosclerosis and cancer. Nat Rev Drug Discov 2007;6:821-33.

35. Ullrich A, Gray A, Tam AW, Yang-Feng T, Tsubokawa M, Collins C, et al. Insulin-like growth factor I receptor primary structure: comparison with insulin receptor suggests structural determinants that define functional specificity. EMBO J 1986;5:2503-12.

36. Frasca F, Pandini G, Scalia P, Sciacca L, Mineo R, Costantino A, et al. Insulin receptor isoform A, a newly recognized, high-affinity insulin-like growth factor II receptor in fetal and cancer cells. Mol Cell Biol 1999;19:3278-88.

37. Mosthaf L, Grako K, Dull TJ, Coussens L, Ullrich A, McClain DA. Functionally distinct insulin receptors generated by tissue-specific alternative splicing. EMBO J 1990;9:2409-13.

38. Pandini G, Conte E, Medico E, Sciacca L, Vigneri R, Belfiore A. IGF-II binding to insulin receptor isoform $\mathrm{A}$ induces a partially different gene expression profile from insulin binding. Ann N Y Acad Sci 2004;1028:450-6.

39. Vella V, Pandini G, Sciacca L, Mineo R, Vigneri R, Pezzino $\mathrm{V}$, et al. A novel autocrine loop involving IGF-II and the insulin receptor isoform-A stimulates growth of thyroid cancer. J Clin Endocrinol Metab 2002;87:245-54.

40. Belfiore A, Malaguarnera R, Vella V, Lawrence MC, Sciacca L, Frasca F, et al. Insulin Receptor Isoforms in Physiology and Disease: An Updated View. Endocr Rev 2017;38:379431

41. Soos MA, Whittaker J, Lammers R, Ullrich A, Siddle $\mathrm{K}$. Receptors for insulin and insulin-like growth factor-I can form hybrid dimers. Characterisation of hybrid receptors in transfected cells. Biochem J 1990;270:383-90.

42. Pandini G, Vigneri R, Costantino A, Frasca F, Ippolito A, Fujita-Yamaguchi Y, et al. Insulin and insulin-like growth factor-I (IGF-I) receptor overexpression in breast cancers leads to insulin/IGF-I hybrid receptor overexpression: evidence for a second mechanism of IGF-I signaling. Clin Cancer Res 1999;5:1935-44.

43. Pandini G, Frasca F, Mineo R, Sciacca L, Vigneri R, Belfiore A. Insulin/insulin-like growth factor I hybrid receptors have different biological characteristics depending on the insulin receptor isoform involved. J Biol Chem 2002;277:39684-95.

44. Belfiore A, Frasca F, Pandini G, Sciacca L, Vigneri R. Insulin receptor isoforms and insulin receptor/insulin-like growth factor receptor hybrids in physiology and disease. Endocr Rev 2009;30:586-623.

45. Bailyes EM, Navé BT, Soos MA, Orr SR, Hayward AC, Siddle K. Insulin receptor/IGF-I receptor hybrids are widely distributed in mammalian tissues: quantification of individual receptor species by selective immunoprecipitation and immunoblotting. Biochem J 1997;327:209-15.

46. Pollak MN, Schernhammer ES, Hankinson SE. Insulin-like growth factors and neoplasia. Nat Rev Cancer 2004;4:505-18.

47. Livingstone C. IGF2 and cancer. Endocr Relat Cancer 2013;20:R321-39.

48. Baquedano MS, Berensztein E, Saraco N, Dorn GV, de 
Davila MT, Rivarola MA, et al. Expression of the IGF system in human adrenal tissues from early infancy to late puberty: implications for the development of adrenarche. Pediatr Res 2005;58:451-8.

49. Mesiano S, Mellon SH, Jaffe RB. Mitogenic action, regulation, and localization of insulin-like growth factors in the human fetal adrenal gland. J Clin Endocrinol Metab 1993;76:968-76.

50. Voutilainen R, Miller WL. Developmental and hormonal regulation of mRNAs for insulin-like growth factor II and steroidogenic enzymes in human fetal adrenals and gonads. DNA 1988;7:9-15.

51. Fottner C, Engelhardt D, Weber MM. Regulation of steroidogenesis by insulin-like growth factors (IGFs) in adult human adrenocortical cells: IGF-I and, more potently, IGF-II preferentially enhance androgen biosynthesis through interaction with the IGF-I receptor and IGF-binding proteins. J Endocrinol 1998;158:409-17.

52. l'Allemand D, Penhoat A, Blum W, Saez JM. Is there a local IGF-system in human adrenocortical cells? Mol Cell Endocrinol 1998;140:169-73.

53. Weber MM, Simmler $P$, Fottner $C$, Engelhardt $D$. Insulinlike growth factor II (IGF-II) is more potent than IGF-I in stimulating cortisol secretion from cultured bovine adrenocortical cells: interaction with the IGF-I receptor and IGFbinding proteins. Endocrinology 1995;136:3714-20.

54. Fottner C, Engelhardt D, Elmlinger MW, Weber MM. Identification and characterization of insulin-like growth factor (IGF)-binding protein expression and secretion by adult human adrenocortical cells: differential regulation by IGFs and adrenocorticotropin. J Endocrinol 2001;168:465-74.

55. Ilvesmäki V, Blum WF, Voutilainen R. Insulin-like growth factor binding proteins in the human adrenal gland. Mol Cell Endocrinol 1993;97:71-9.

56. Ronchi CL, Sbiera S, Leich E, Henzel K, Rosenwald A, Allolio B, et al. Single nucleotide polymorphism array profiling of adrenocortical tumors-evidence for an adenoma carcinoma sequence? PLoS One 2013;8:e73959.

57. Ilvesmäki V, Kahri AI, Miettinen PJ, Voutilainen R. Insulin-like growth factors (IGFs) and their receptors in adrenal tumors: high IGF-II expression in functional adrenocortical carcinomas. J Clin Endocrinol Metab 1993;77:852-8.

58. Nielsen HM, How-Kit A, Guerin C, Castinetti F, Vollan HK, De Micco C, et al. Copy number variations alter methylation and parallel IGF2 overexpression in adrenal tumors. Endocr Relat Cancer 2015;22:953-67.

59. De Fraipont F, Le Moigne G, Defaye G, El Atifi M, Berger F, Houlgatte R, et al. Transcription profiling of benign and malignant adrenal tumors by cDNA macro-array analysis. Endocr Res 2002;28:785-6.

60. Bahadir CT, Ecemis GC, Atmaca H. Does IGF-1 play a role in the etiopathogenesis of non-functioning adrenocortical adenoma? J Endocrinol Invest 2018.

61. Scaroni C, Selice R, Benedini S, De Menis E, Arosio M, Ronchi $\mathrm{C}$, et al. Adrenal morpho-functional alterations in patients with acromegaly. J Endocrinol Invest 2008;31:602-6.

62. Pappa T, Papanastasiou L, Koutmos S, Tsiavos V, Roussaki P, Zilos A, et al. Pattern of adrenal morphology and function in patients with acromegaly. Eur J Clin Invest $2012 ; 42: 275-81$.

63. Reincke M, Fassnacht M, Väth S, Mora P, Allolio B. Adrenal incidentalomas: a manifestation of the metabolic syndrome? Endocr Res 1996;22:757-61.

64. Muscogiuri G, Sorice GP, Prioletta A, Mezza T, Cipolla $\mathrm{C}$, Salomone $\mathrm{E}$, et al. The size of adrenal incidentalomas cor- relates with insulin resistance. Is there a cause-effect relationship? Clin Endocrinol (Oxf) 2011;74:300-5.

65. Giordano TJ, Kuick R, Else T, Gauger PG, Vinco M, Bauersfeld J, et al. Molecular classification and prognostication of adrenocortical tumors by transcriptome profiling. Clin Cancer Res 2009;15:668-76.

66. Almeida MQ, Fragoso MC, Lotfi CF, Santos MG, Nishi MY, Costa MH, et al. Expression of insulin-like growth factor-II and its receptor in pediatric and adult adrenocortical tumors. J Clin Endocrinol Metab 2008;93:3524-31.

67. Logié A, Boulle N, Gaston V, Perin L, Boudou P, Le Bouc $\mathrm{Y}$, et al. Autocrine role of IGF-II in proliferation of human adrenocortical carcinoma NCI H295R cell line. J Mol Endocrinol 1999;23:23-32.

68. Cantini G, Lombardi A, Piscitelli E, Poli G, Ceni E, Marchiani $\mathrm{S}$, et al. Rosiglitazone inhibits adrenocortical cancer cell proliferation by interfering with the IGF-IR intracellular signaling. PPAR Res 2008;2008:904041.

69. Gicquel $C$, Bertagna $X$, Schneid $H$, Francillard-Leblond M, Luton JP, Girard F, et al. Rearrangements at the $11 \mathrm{p} 15$ locus and overexpression of insulin-like growth factor-II gene in sporadic adrenocortical tumors. J Clin Endocrinol Metab 1994; 78:1444-53.

70. Gicquel C, Raffin-Sanson ML, Gaston V, Bertagna X, Plouin PF, Schlumberger M, et al. Structural and functional abnormalities at $11 \mathrm{p} 15$ are associated with the malignant phenotype in sporadic adrenocortical tumors: study on a series of 82 tumors. J Clin Endocrinol Metab 1997;82:2559-65.

71. Gao ZH, Suppola S, Liu J, Heikkilä P, Jänne J, Voutilainen R. Association of $\mathrm{H} 19$ promoter methylation with the expression of H19 and IGF-II genes in adrenocortical tumors. J Clin Endocrinol Metab 2002;87:1170-6.

72. Creemers SG, van Koetsveld PM, van Kemenade FJ, Papathomas TG, Franssen GJ, Dogan F, et al. Methylation of IGF2 regulatory regions to diagnose adrenocortical carcinomas. Endocr Relat Cancer 2016;23:727-37.

73. Guillaud-Bataille $M$, Ragazzon B, de Reyniès A, Chevalier C, Francillard I, Barreau O, et al. IGF2 promotes growth of adrenocortical carcinoma cells, but its overexpression does not modify phenotypic and molecular features of adrenocortical carcinoma. PLoS One 2014;9:e103744.

74. Heaton JH, Wood MA, Kim AC, Lima LO, Barlaskar FM, Almeida MQ, et al. Progression to adrenocortical tumorigenesis in mice and humans through insulin-like growth factor 2 and $\beta$-catenin. Am J Pathol 2012;181:1017-33.

75. Boulle N, Logié A, Gicquel C, Perin L, Le Bouc Y. Increased levels of insulin-like growth factor II (IGF-II) and IGF-binding protein-2 are associated with malignancy in sporadic adrenocortical tumors. J Clin Endocrinol Metab 1998;83:1713-20.

76. Babińska A, Pęksa R, Wiśniewski P, ŚwiatkowskaStodulska R, Sworczak K. Diagnostic and prognostic role of $\mathrm{SF} 1$, IGF2, Ki67, p53, adiponectin, and leptin receptors in human adrenal cortical tumors. J Surg Oncol 2017;116:427-33.

77. Edgren M, Eriksson B, Wilander E, Westlin JE, Nilsson S, Oberg K. Biological characteristics of adrenocortical carcinoma: a study of p53, IGF, EGF-r, Ki-67 and PCNA in 17 adrenocortical carcinomas. Anticancer Res 1997;17(2B):1303-9.

78. Fassnacht M, Weismann D, Ebert S, Adam P, Zink M, Beuschlein $\mathrm{F}$, et al. AKT is highly phosphorylated in pheochromocytomas but not in benign adrenocortical tumors. Clin Endocrinol Metab 2005;90:4366-70.

79. Shi Z, Henwood MJ, Bannerman P, Batista D, Horvath A, Guttenberg $\mathrm{M}$, et al. Primary pigmented nodular adrenocortical disease reveals insulin-like growth factor binding pro- 
tein- 2 regulation by protein kinase A. Growth Horm IGF Res 2007; 17:113-21.

80. Boulle N, Baudin E, Gicquel C, Logié A, Bertherat J, Penfornis A, et al. Evaluation of plasma insulin-like growth factor binding protein-2 as a marker for adrenocortical tumors. Eur J Endocrinol 2001;144:29-36.

81. Wilkin F, Gagné N, Paquette J, Oligny LL, Deal C. Pediatric adrenocortical tumors: molecular events leading to insulin-like growth factor II gene overexpression. J Clin Endocrinol Metab 2000;85:2048-56.

82. Peixoto Lira RC, Fedatto PF, Marco Antonio DS, Leal LF, Martinelli CE, de Castro M, et al. IGF2 and IGF1R in pediatric adrenocortical tumors: roles in metastasis and steroidogenesis. Endocr Relat Cancer 2016;23:481-93.

83. Rosati R, Cerrato F, Doghman M, Pianovski MA, Parise GA, Custódio G, et al. High frequency of loss of heterozygosity at $11 \mathrm{p} 15$ and IGF2 overexpression are not related to clinical outcome in childhood adrenocortical tumors positive for the R337H TP53 mutation. Cancer Genet Cytogenet 2008;186:19-24.

84. Doghman M, El Wakil A, Cardinaud B, Thomas E, Wang $\mathrm{J}$, Zhao W, et al. Regulation of insulin-like growth factor-mammalian target of rapamycin signaling by microRNA in childhood adrenocortical tumors. Cancer Res 2010;70:4666-75.

85. Aleksic T, Chitnis MM, Perestenko OV, Gao S, Thomas $\mathrm{PH}$, Turner GD, et al. Type 1 insulin-like growth factor receptor translocates to the nucleus of human tumor cells. Cancer Res 2010;70:6412-9.

86. Ribeiro TC, Jorge AA, Montenegro LR, Almeida MQ, Ferraz-de-Souza B, Nishi MY, et al. Effects of Type 1 InsulinLike Growth Factor Receptor Silencing in a Human Adrenocortical Cell Line. Horm Metab Res 2016;48:484-8.

87. Buck E, Gokhale PC, Koujak S, Brown E, Eyzaguirre A, Tao N, et al. Compensatory insulin receptor (IR) activation on inhibition of insulin-like growth factor-1 receptor (IGF-1R): rationale for cotargeting IGF-1R and IR in cancer. Mol Cancer Ther 2010;9:2652-64.

88. Forest A, Amatulli M, Ludwig DL, Damoci CB, Wang Y, Burns CA, et al. Intrinsic Resistance to Cixutumumab Is Conferred by Distinct Isoforms of the Insulin Receptor. Mol Cancer Res 2015;13:1615-26.
89. Lerario AM, Worden FP, Ramm CA, Hesseltine EA, Stadler WM, Else T, et al. The combination of insulin-like growth factor receptor 1 (IGF1R) antibody cixutumumab and mitotane as a first-line therapy for patients with recur$\mathrm{rent} / \mathrm{metastatic}$ adrenocortical carcinoma: a multi-institutional NCI-sponsored trial. Horm Cancer 2014;5:232-9.

90. Weigel B, Malempati S, Reid JM, Voss SD, Cho SY, Chen HX, et al. Phase 2 trial of cixutumumab in children, adolescents, and young adults with refractory solid tumors: a report from the Children's Oncology Group. Pediatr Blood Cancer 2014;61:452-6.

91. Jones RL, Kim ES, Nava-Parada P, Alam S, Johnson FM, Stephens AW, et al. Phase I study of intermittent oral dosing of the insulin-like growth factor-1 and insulin receptors inhibitor OSI-906 in patients with advanced solid tumors. Clin Cancer Res 2015;21:693-700.

92. Naing A, Kurzrock R, Burger A, Gupta S, Lei X, Busaidy $\mathrm{N}$, et al. Phase I trial of cixutumumab combined with temsirolimus in patients with advanced cancer. Clin Cancer Res 2011;17:6052-60.

93. Simpson A, Petnga W, Macaulay VM, Weyer-Czernilofsky U, Bogenrieder T. Insulin-Like Growth Factor (IGF) Pathway Targeting in Cancer: Role of the IGF Axis and Opportunities for Future Combination Studies. Target Oncol 2017;12:571-97.

94. De Martino MC, van Koetsveld PM, Feelders RA, SprijMooij D, Waaijers M, Lamberts SW, et al. The role of mTOR inhibitors in the inhibition of growth and cortisol secretion in human adrenocortical carcinoma cells. Endocr Relat Cancer 2012;19:351-64.

95. Pollak M. Potential applications for biguanides in oncology. J Clin Invest 2013;123:3693-700.

96. Zi F, Zi H, Li Y, He J, Shi Q, Cai Z. Metformin and cancer: an existing drug for cancer prevention and therapy. Oncol Lett 2018;15:683-90.

97. Poli G, Cantini G, Armignacco R, Fucci R, Santi R, Canu $\mathrm{L}$, et al. Metformin as a new anti-cancer drug in adrenocortical carcinoma. Oncotarget 2016;7:49636-48.

98. Brown RE, Buryanek J, McGuire MF. Metformin and Melatonin in Adrenocortical Carcinoma: Morphoproteomics and Biomedical Analytics Provide Proof of Concept in a Case Study. Ann Clin Lab Sci 2017;47:457-65.

Conflicts of interest.-The authors certify that there is no conflict of interest with any financial organization regarding the material discussed in the manuscript.

Article first published online: July 2, 2018. - Manuscript accepted: September 12, 2018. - Manuscript received: June 18, 2018. 